\title{
Atom-Precise Fluorescent Copper Cluster for Tumor Microenvironment Targeting and Transient Chemodynamic Cancer Therapy
}

\section{Zhenzhen Yang}

Zhengzhou University First Affiliated Hospital

\section{Anli Yang}

Sun Yat-sen University Cancer Center

\section{Wang Ma}

Zhengzhou University First Affiliated Hospital

\section{Kai Ma}

Zhengzhou University

Ya-Kun Lv

Zhengzhou University

\section{Peng Peng}

Zhengzhou University

\section{Bingjie Li ( $\sim$ bingjieli1991@outlook.com )}

Zhengzhou University First Affiliated Hospital https://orcid.org/0000-0002-6540-5557

\section{Shuang-Quan Zang}

Zhengzhou University

\section{Research Article}

Keywords: nano clusters, sustainable release, targeting property, ROS, cancer therapy

Posted Date: September 7th, 2021

DOI: https://doi.org/10.21203/rs.3.rs-853200/v1

License: (c) (1) This work is licensed under a Creative Commons Attribution 4.0 International License.

Read Full License

Version of Record: A version of this preprint was published at Journal of Nanobiotechnology on January 6th, 2022. See the published version at https://doi.org/10.1186/s12951-021-01207-6. 


\section{Abstract}

Background: Reactive oxygen species (ROS) have been widely studied for cancer therapy. Nevertheless, instability and aspecific damages to cellular biomolecules limited the application effect. Recently, significant research efforts have been witnessed in the flourishing area of metal nanoclusters (NCs) with atomically precise structures for targeted release of ROS but few achieved success towards targeting tumor microenvironment.

Results: In this work, we reported an atomically precise nanocluster $\mathrm{Cu}_{6}\left(\mathrm{C}_{4} \mathrm{H}_{3} \mathrm{~N}_{2} \mathrm{~S}\right)_{6}\left(\mathrm{Cu}_{6} \mathrm{NC}\right)$, which could slowly break and generate ROS once encountered with acidic. The as-prepared $\mathrm{Cu}_{6} \mathrm{NC}$ demonstrated high biological safety and efficient chemodynamic anti-tumor properties. Moreover, $\mathrm{Cu}_{6} \mathrm{NC}$ enabled transient release of ROS and contained targeting behavior led by the tumor microenvironment. Both in vitro and in vivo experiments confirmed that $\mathrm{Cu}_{6} \mathrm{NC}$ demonstrated a low cytotoxicity for normal cells, while presented high cytotoxicity for tumor cells with a concentration-dependent manner.

Conclusions: This work not only reported a promising candidate for chemodynamic cancer therapy, but also paved the route to address clinical issues at the atomic level.

\section{Introduction}

Reactive oxygen species (ROS) are unstable molecules that contain oxygen, such as singlet oxygen, superoxide, hydroxyl radical and peroxide, etc. For the last decades, both experimental and clinical studies confirm that the alterations of ROS can affect the intracellular redox state.[1-3] Ever since, numerous efforts have been devoted to examine the role of ROS in cellular transformation and tumorigenesis. $[4,5]$ It has been observed that raising ROS level could effectively promote the apoptosis of cancer cells and modulate the immune response (specifically, inhibition) towards the treatment of cancer as well as autoimmune diseases.[6-8] Moreover, elevation of ROS levels also contribute to tissue regeneration.[9] Many treatments such as the exposure of cancer cells to chemotherapy and radiotherapy could upregulate ROS.[10-12] Nevertheless, caused by the intrinsic instability, it is difficult for ROS to realize sustainable release for persistent anti-cancer effect. Meanwhile, a well-coordinated and balanced redox system is typically present under normal physiological conditions. Thus, promoting ROS may produce cellular stress and damage, since ROS can damage cellular biomolecules (such as proteins, DNA, RNA) and result in mutations or even carcinogenesis. Hence, the controllable presentation of ROS is vital to take advantage of this double-edged sword for cancer therapy.

Over the past decades, remarkable progress has been achieved in the area of nanomaterials such as atomically precise assembled nanoclusters.[13-15] Amongst the nanoclusters, atomically precise metal nanoclusters (NCs) has explored promising potentials with fine-tuned properties.[16-18] The bottom-up programmed assembly of these NCs make it relatively simple to control over the size and to replace the surface organic ligand, providing good opportunities for particular applications.[19-23] By far, various metal based NCs (especially gold) have demonstrated effective anti-cancer properties.[24, 25] For 
example, researchers have developed NCs that could make cancer cells more sensitive to radiation and promote the efficiency of radiotherapy.[26-29] Our previous work also explored photothermic behavior from coordinated-metal centers for cancer therapy.[30] By far, our group have designed and synthesized dozens of metal NCs with atomically precise assembly.[31-37] Benefiting from the precise formulas, both the structure and the physicochemical properties of atomically precise metal NCs are controllable. $[38,39]$ Thus, one could reasonably hypothesize that with rationale design, the additional introduction of the organic ligand could modulate targeting properties while the functional modification may generate sustained releasement of NCs in particular position.

Herein, we reported an atomically precise nanocluster $\mathrm{Cu}_{6}\left(\mathrm{C}_{4} \mathrm{H}_{3} \mathrm{~N}_{2} \mathrm{~S}\right)_{6}$, which were determined by the single crystal X-ray diffraction (SC-XRD). 2-mercaptopyrimidine was used to assemble the precise structures and led to a size of $\sim 1 \mathrm{~nm}$, which was much smaller than the kidney filtration threshold. Consistently, none of cardiotoxicity, kidney toxicity or liver toxicity were observed the main organs and peripheral blood, suggesting the good compatibility of our $\mathrm{Cu}_{6} \mathrm{NC}$. Specially, the structure $\mathrm{Cu}_{6}\left(\mathrm{C}_{4} \mathrm{H}_{3} \mathrm{~N}_{2} \mathrm{~S}\right)_{6}$ was quite stable unless mixed in acidic environment. The slight addition of acid $(\mathrm{pH} \sim 6)$ would slowly break the structure and generate the burst of radicals, realizing the sustained releasement of ROS (Scheme 1). The in vitro and in vivo experiments confirmed that $\mathrm{Cu}_{6} \mathrm{NC}$ demonstrated a low cytotoxicity for normal cells, while presented high cytotoxicity for tumor cells with a concentration-dependent manner (Scheme 1). Such observations not only confirmed the biological safety and chemodynamic anti-tumor properties, but also indicated the targeting behavior led by the tumor microenvironment.

\section{Results And Discussions}

\subsection{Synthesis and characterization of $\mathrm{Cu}_{6}\left(\mathrm{C}_{4} \mathrm{H}_{3} \mathrm{~N}_{2} \mathrm{~S}\right)_{6}$ nanoclusters. Typically, the}

$\mathrm{Cu}_{6}\left(\mathrm{C}_{4} \mathrm{H}_{3} \mathrm{~N}_{2} \mathrm{~S}\right)_{6}$ nanocluster $\left(\mathrm{Cu}_{6} \mathrm{NC}\right)$ was synthesized via one-pot route by blending 2mercaptopyrimidine with $\mathrm{Cu}\left(\mathrm{NO}_{3}\right)_{2} \cdot 3 \mathrm{H}_{2} \mathrm{O}$ (ratio of $1 / 1$ by mole) in dimethyl formamide (detailed in experimental section). As revealed by SC-XRD, the hexagonal prismatic structure of $\mathrm{Cu}_{6}\left(\mathrm{C}_{4} \mathrm{H}_{3} \mathrm{~N}_{2} \mathrm{~S}\right)_{6}$ was composed of a hexagonal prismatic Cu6 kernel which was stabilized and sealed by the introduced six 2mercaptopyrimidine (Fig. 1a and Additional file 1: Table S1). As shown in Fig. 1b, the experimental Powder-XRD (PXRD) patterns were good agreement with the simulated ones from the SC-XRD, indicating the phase purity of the as-synthesized crystalline products of $\mathrm{Cu}_{6} \mathrm{NC}$. X-Ray photoelectron spectroscopy (XPS) (Additional file 1: Figure S1a) confirmed that $\mathrm{Cu}_{6} \mathrm{NC}$ contained $\mathrm{C}, \mathrm{N}, \mathrm{S}$ and $\mathrm{Cu}$ elements. The peaks at 932.6 and $952.5 \mathrm{eV}$ in the high-resolution $\mathrm{Cu} 2 \mathrm{p}$ spectrum (Additional file 1: Figure S1b) could be attributed to the $2 p_{2 / 3}$ and $2 p_{1 / 2}$ of $\mathrm{Cu}^{+}$, respectively,[40,41] which was generated by the reductive mercapto groups. In the Fourier transform infrared (FTIR) spectra (Additional file 1: Figure S2), the adsorption peaks of $\mathrm{S}-\mathrm{H}$ stretch were absent in the spectra of $\mathrm{Cu}_{6} \mathrm{NC}$ and the $\mathrm{C}=\mathrm{C} / \mathrm{C}=\mathrm{N}$ peaks were apparently red-shifted, suggesting the formation of the coordination between mercaptopyrimidine and $\mathrm{Cu}$ ions.[42] Such coordinated ligands led to considerable thermal stabilities. Under nitrogen atmosphere, the 
thermogravimetric analysis (TGA) revealed that $\mathrm{Cu}_{6} \mathrm{NC}$ could be maintained from room temperature to nearly $400{ }^{\circ} \mathrm{C}$ and the total weight loss of $\mathrm{Cu}_{6} \mathrm{NC}$ achieved $\sim 50 \%$ at $800{ }^{\circ} \mathrm{C}$ (Additional file 1 : Figure S3).

Notably, $\mathrm{Cu}_{6} \mathrm{NC}$ demonstrated crucial luminescent properties, indicating potential applications for biomedical labeling and targeting. The normalized emission spectra of the $\mathrm{Cu}_{6} \mathrm{NC}$ showed longwavelength emission bands of $700 \mathrm{~nm}$ (Additional file 1: Figure S4), which was appealing for the biological test. According to dynamic light scattering (DLS) analysis, the lateral size of $\mathrm{Cu}_{6} \mathrm{NC}$ components in aqueous was $\sim 23 \mathrm{~nm}$ (Additional file 1: Figure S5), which was within the range enabling efficient uptake by tumors. Moreover, obvious light absorption of $\mathrm{Cu}_{6} \mathrm{NC}$ was observed at the wavelength of $370 \mathrm{~nm}$ during the solid state UV-vis test (Additional file 1: Figure S6). Since the structure was quite stable in water, we further tracked the UV-vis curves of $\mathrm{Cu}_{6} \mathrm{NC}$ in the $\mathrm{HCl}$ solution $(\mathrm{pH} \sim 6)$, observing a slowly structure changes (Fig. 1c). Meanwhile, the PXRD revealed that the crystalline structures of $\mathrm{Cu}_{6} \mathrm{NC}$ were totally broken (Additional file 1: Figure S7). More importantly, electron paramagnetic response (EPR) of $\mathrm{Cu}_{6} \mathrm{NC}$ displayed significantly changed signals with the addition of $\mathrm{HCl}$ solution $(\mathrm{pH} \sim 6)$ (Fig. 1d), proving that a large number of ROS was produced during the structural fragmentation of $\mathrm{Cu}_{6} \mathrm{NC}$. The morphology analysis by scanning electron microscopy (SEM) and the associated energy disperses spectroscopy (EDS) also revealed that the crystalline $\mathrm{Cu}_{6} \mathrm{NC}$ with clear shape (Fig. 1e and Additional file 1: Figure S8) was totally pulverized (Fig. $1 \mathrm{f}$ and Additional file 1: Figure S9) after the treatment of acidic solution $(\mathrm{pH} \sim 6)$.

2.2 Cytotoxicity studies of $\mathrm{Cu}_{6} \mathrm{NC}$. The biological safety of $\mathrm{Cu}_{6} \mathrm{NC}$ was evaluated by cell viability. Both normal (cardiomyocytes, $\mathrm{H} 9 \mathrm{C} 2$ ) and cancer cell lines were used as models to assess cellular responses by CCK-8 assay kit. $\mathrm{Cu}_{6} \mathrm{NC}$ demonstrated high cytotoxicity to tumor cells (Additional file 1: Figure $\mathrm{S} 10$ and Fig. 2a). After treatment with $20 \mu \mathrm{M} \mathrm{Cu}{ }_{6} \mathrm{NC}$ for $48 \mathrm{~h}$, the cell viability of A375, MCF-7 and Kyse30 cancer cell lines were $26.3 \%, 19.6 \%$, and $20.9 \%$, respectively (Fig. 2a). On the contrary, low cytotoxicity was observed to normal cardiomyocytes (Fig. 2b). After $48 \mathrm{~h}$ of incubation, the inhibition rate of $20 \mu \mathrm{M} \mathrm{Cu} \mathrm{NC}_{6}$ was only $49.3 \%$ and the cell viability was $78.5 \%$ at the $15 \mu \mathrm{M}$ (administration level), which was much higher that tumor cells at the same level. Notably, we also measured the the cellular uptake capacity of $\mathrm{Cu}_{6} \mathrm{NC}$ into both $\mathrm{A} 375$ cells and normal cardiomyocytes (Fig. 2c and 2d) during flow cytometric test. Along with the increase of incubation durations, the proportion of positive cells was slightly raised in cardiomyocytes while obviously promoted in cancer cells, suggesting the much more effective adsorption of $\mathrm{Cu}_{6} \mathrm{NC}$ by tumor cells. These phenomena confirmed that $\mathrm{Cu}_{6} \mathrm{NC}$ was tumor-specific.

2.3 Investigations of anti-tumor properties. Due to the selective cytotoxic propertiy, $\mathrm{Cu}_{6} \mathrm{NC}$ was thoroughly evaluated for chemodynamic therapy (CDT) in vitro. The four groups of cells treated with different concentrations of $\mathrm{Cu}_{6} \mathrm{NC}(0,2,8$ and $16 \mu \mathrm{M})$ were analyzed. Subsequently, the apoptosis and cycle were evaluated by flow cytometry $24 \mathrm{~h}$. As shown in Fig. 3a and Additional file 1: Figure S11, $\mathrm{Cu}_{6} \mathrm{NC}$ promoted the apoptosis of $\mathrm{A} 375$ cells, thereby causing cell proliferation inhibition. Particularly, $\mathrm{Cu}_{6} \mathrm{NC}$ could mediate cell arrest in G2 phase (Fig. 3b and Additional file 1: Figure S12). Live/dead stain imaging 
showed more red fluorescence appeared with the increased concentration of $\mathrm{Cu}_{6} \mathrm{NC}$ (Fig. 2e), suggesting that the viability of cells in the $\mathrm{Cu}_{6} \mathrm{NC}$ decreased in a dose-dependent manner. Meanwhile, live/dead detection associated with flow cytometry (Additional file 1: Figure S13 and S14) also demonstrated that after incubation with $0,2,8$ and $16 \mu \mathrm{M} \mathrm{Cu}_{6} \mathrm{NC}$, the cell death rates were $3.63 \%, 7.14 \%, 23.0 \%$ and $42.2 \%$, respectively. Since the formidable metastasis ability is one of the reasons that tumor cells are difficult to completely clean, we also performed transwell migration assay in vitro and observed that $\mathrm{Cu}_{6} \mathrm{NC}$ could significantly inhibit tumor cells migration (Fig. 3c and Additional file 1: Figure S15). Furthermore, the cell colony formation assay was conducted to assess the chemodynamic efficacy of $\mathrm{Cu}_{6} \mathrm{NC}$ over a longer period of time. The corresponding results revealed similar dose-dependent (Fig. 3d and Additional file 1: Figure S16). In the control group $(0 \mu \mathrm{M})$, the colonies were densely packed and none effect on cell proliferation was observed. Specifically, the cell survival fraction obviously decreased with the addition of $\mathrm{Cu}_{6} \mathrm{NC}$. In the $16 \mu \mathrm{M}$ group, even almost no colonies appeared, indicating that $\mathrm{Cu}_{6} \mathrm{NC}$ were excellent for CDT.

$\mathrm{Cu}_{6} \mathrm{NC}$ induced considerable oxidative stress in vitro, leading to specific tumor killing effect. Since ROS was detected during EPR test, we explored the underlying mechanisms of $\mathrm{Cu}_{6} \mathrm{NC}$ for $\mathrm{CDT}$ and detected the intracellular ROS by the probe DCFH-DA, which displayed green fluorescence upon oxidation by ROS. For $\mathrm{A} 375$ cells exposed to $\mathrm{Cu}_{6} \mathrm{NC} 12 \mathrm{~h}$, the observed green fluorescence intensity was enhanced with the increasing of concentration (Fig. 3e and Additional file 1: Figure S17), suggesting production of ROS via $\mathrm{Cu}^{+}$-mediated Fenton reaction. Moreover, we found that the ratio of GSH/GSSG in A375 cells treated with $\mathrm{Cu}_{6} \mathrm{NC}$ for $6 \mathrm{~h}$ was significantly reduced in a concentration-dependent manner (Additional file 1: Figure S18), which also indicated that the higher intracellular GSH levels in tumor cells could also be one of the possible mechanisms.

2.4 In vivo cancer therapy. Inspired by the good in vitro CDT efficacy, tumor formation assay was performed in vivo by using human melanoma A375 tumor-bearing mice model. Mice with tumors of about $100 \mathrm{~mm}^{3}$ were randomly divided into three groups: (1) Control group, (2) $\mathrm{Cu}_{6} \mathrm{NC}$ group (10 mg/kg), and (3) $\mathrm{Cu}_{6} \mathrm{NC}$ group $\left(20 \mathrm{mg} / \mathrm{kg}\right.$ ). According to the corresponding dose of each group, $\mathrm{Cu}_{6} \mathrm{NC}$ were administered intraperitoneally every two days. The tumor volume was measured every other day (Fig. 4a and $4 \mathrm{~b}$ ). At the time of final harvest, the tumor volume in the Control group increased rapidly, while in the dose of $20 \mathrm{mg} / \mathrm{kg}$ group the tumor volume was markedly reduced by about 4.5 times (compared with the Control group). Besides, the measured tumor weight also decreased significantly with the increase of the treatment dose (Fig. 4d). To verify the inhibitory effect of $\mathrm{Cu}_{6} \mathrm{NC}$, the proliferation and apoptosis in tumor tissues from each group was further detected. According to the immunohistochemical staining, the Ki67 protein level of the $\mathrm{Cu}_{6} \mathrm{NC}$ treatment group was significantly lower than that of the Control group (Fig. 4c and 4e). Consistently, the TUNEL staining also demonstrated a promotion with the increase of the administration concentration (Fig. $4 \mathrm{c}$ and $4 \mathrm{f}$ ), further proving the ability of $\mathrm{Cu}_{6} \mathrm{NC}$ to induce apoptosis.

To evaluate the in vivo biocompatibility of $\mathrm{Cu}_{6} \mathrm{NC}$, the main organs and peripheral blood of the mice were investigated after the mice were sacrificed. Specifically, H\&E staining results of the mice in every groups 
showed that no major pathological abnormalities was induced in main organs of mice (Fig. 4g). Concomitantly, none of cardiotoxicity, kidney toxicity or liver toxicity from $\mathrm{Cu}_{6} \mathrm{NC}$ was observed in the blood samples (Additional file 1: Figure S19), indicating the low in vivo toxicity of $\mathrm{Cu}_{6} \mathrm{NC}$.

\section{Conclusions}

ROS are unstable oxygen containing species, which make it difficult to be persistently subsistent and effective in clinical treatment. On the other hand, lacking of natural targeted properties, the surplus ROS are harmful to normal cells, generating damages or carcinogenesis. In this study, we designed and prepared $\mathrm{Cu}_{6} \mathrm{NC}$ with atomically precisely structures of $\mathrm{Cu}_{6}\left(\mathrm{C}_{4} \mathrm{H}_{3} \mathrm{~N}_{2} \mathrm{~S}\right)_{6}$, which could generate large amount of ROS in acidic environment. Such characters address the above conundrum: (1) $\mathrm{Cu}_{6} \mathrm{NC}$ could slowly degrade and sustainably release ROS; (2) the fragmentation of $\mathrm{Cu}_{6} \mathrm{NC}$ are induced under acidic environment, providing targeted properties. Thus, $\mathrm{Cu}_{6} \mathrm{NC}$ could be fragmented under the acidic tumor microenvironment with sustainable burst of ROS. Both in vitro and in vivo experiments confirm that $\mathrm{Cu}_{6} \mathrm{NC}$ not only present high cytotoxicity to tumor cells, but also ensure the biological safety. Our intelligent strategy not only develops a promising candidate for the targeted chemodynamic therapy of cancer cells, but also paves the way for addressing clinical issues at the atomic level.

\section{Experimental Section}

Synthesis of $\mathrm{Cu}_{6}\left(\mathrm{C}_{4} \mathrm{H}_{3} \mathrm{~N}_{2} \mathrm{~S}\right)_{6}$. 2-Mercaptopyrimidine ( $\geq 99 \%$ ) were purchased from Alfa Aesar. DMF and Copper nitrate trihydrate( $(\mathrm{Z})\left(\mathrm{Cu}(\mathrm{NO})_{3}, \geq 99 \%\right)$ were bought from Sinopharm Chemical Reagent $\mathrm{Co}$., Ltd., China. All reagents and solvents used were of commercially available reagent grade and used without further purification. 2-Mercaptopyrimidine (112mg, $1 \mathrm{mmol})$ and $\mathrm{Cu}\left(\mathrm{NO}_{3}\right)_{2} \cdot 3 \mathrm{H}_{2} \mathrm{O}(240 \mathrm{mg}, 1 \mathrm{mmol})$ were dissolved in $20 \mathrm{ml}$ DMF solution respectively, stir thoroughly to dissolve completely. Subsequently, add the DMF solution of 2-Mercaptopyrimidine dropwise to the solvent of $\mathrm{Cu}\left(\mathrm{NO}_{3}\right)_{2} \cdot 3 \mathrm{H}_{2} \mathrm{O} \cdot \mathrm{Cu}_{6} \mathrm{~L}_{6}$ powder crystals $\left(\mathrm{C}_{24} \mathrm{H}_{18} \mathrm{Cu}_{6} \mathrm{~N}_{12} \mathrm{~S}_{6}\right)$ were obtained by filtration after vigorous stirring at room temperature for two hours. (A single crystal suitable for SCXRD measurements can be obtained by reducing the dosage in the same proportion).

Characterization. Powder X-ray diffraction (PXRD) patterns of the samples were acquired on on a Riguku D/Max-2500PC X-ray diffractometer with Cu radiation $(\lambda=1.54178 \AA$ ). Fourier transform infrared (FT-IR) spectroscopy was conducted using a Bruker ALPHA II FT-IR spectrometer. X-ray photoelectron spectroscopy (XPS) analysis was obtained on an ESCALAB 250 instrument operated at $150 \mathrm{~W}$ and 200 $\mathrm{eV}$ with mono chromated Al Ka radiation. Thermogravimetric analyses (TGA) were performed on an SDT 2960 thermal analyzer from room temperature (RT) to $800^{\circ} \mathrm{C}$ at a heating rate of $10^{\circ} \mathrm{C} / \mathrm{min}$ under a nitrogen atmosphere. Dynamic light scattering (DLS) data were obtained by Horiba nano Partica SZ100V2. UV-vis absorption spectra were recorded using a Hitachi UH4150 UV-visible spectrophotometer in the range of 200-700 nm. Emission and excitation spectra at RT were recorded with an Edinburgh FLS 1000 fluorescence spectrometer, and luminescence microscopy images were recorded on an Olympus 
BX53 microscope. Electron paramagnetic resonance (EPR) spectra were recorded by a Bruker A 300 EPR spectrometer.

Single-Crystal X-ray Diffraction (SCXRD) analysis. SCXRD was performed on a Rigaku XtaLAB Pro diffractometer Cu-Ka radiation $(\lambda=1.54184 \AA)$ at $200 \mathrm{~K}$. Data collection and reduction were conducted with CrysAlisPro software. The structures were solved with intrinsic phasing methods (SHELXT-2015) and refined by full-matrix least squares on F2 using OLEX2, which utilizes the SHELXL-2015 module. The imposed restraints in least-squares refinement of each structure were commented in the corresponding CIF files. All non-hydrogen atoms were refined anisotropically, and the hydrogen atoms were included on idealized positions. The crystal structures are visualized by DIAMOND 3.2. The detailed information of the crystal data, data collection and refinement results are summarized in Table S1.

Cell Culture. Cell lines including human melanoma cells (A375), human esophageal cancer cells (Kyse30), human breast cancer cells (MCF-7) and Rat cardiomyocytes cells (H9C2) were purchased from the cell bank of the Chinese Academy of Sciences (Shanghai, China). A375 and H9C2 cells were cultured in DMEM medium containing 10\% FBS and 1\% penicillin-streptomycin. MCF-7 and Kyse30 cells incubated in 1640 medium containing 10\% FBS and 1\% penicillin-streptomycin.

Cytotoxicity Analysis. A375, MCF-7 and Kyse30 cells were seeded in 96 -well plates ( $8 \times 10^{3}$ cells per well), respectively, and cultured for overnight. Then these cells were incubated with different concentrations of $\mathrm{Cu}_{6} \mathrm{NC}(0,2,4,8,12,15,20$ and $25 \mu \mathrm{M})$, the incubation time was 24 hours and 48 hours, respectively. Finally, add $10 \mu \mathrm{L}$ of CCK-8 solution to each well and incubate for another $1 \mathrm{~h}$. The absorbance of cells in each well at $450 \mathrm{~nm}$ was measured by a microplate reader. The cytotoxicity test of $\mathrm{Cu}_{6} \mathrm{NC}$ on $\mathrm{H} 9 \mathrm{C} 2$ cells was also carried out according to the above description.

\section{Cellular Uptake of $\mathrm{Cu}_{6} \mathrm{NC}$}

A375 and H9C2 cells were seeded in culture dishes and incubated for $24 \mathrm{~h}$. Subsequently, cells were incubated with $8 \mu \mathrm{M}$ Cu6NC and harvested after $3 \mathrm{~h}$ and $6 \mathrm{~h}$. The percentage of positive cells was tested by the flow cytometry (ACEA NovoCyte3130, USA) with an excitation wavelength of $405 \mathrm{~nm}$ and an emission wavelength of $780 \mathrm{~nm}$. Data were processed by FlowJo software.

Apoptosis and Cell Cycle Analysis. A375 $\left(2.5 \times 10^{5}\right.$ cells per well) cells were seeded in 6-well plates with 0 , 2,8 and $16 \mu \mathrm{M} \mathrm{Cu}_{6} \mathrm{NC}$ for 24 hours. The cells were collected using trypsin-EDTA and stained with annexin V-FITC/PI (BD Biosciences, USA) for $15 \mathrm{~min}, \mathrm{f}$ and then apoptotic cells were identified by flow cytometry. The cell cycle was measured by PI staining using a cell cycle analysis kit (KeyGen Biotech, China). After staining following the manufacturer's instructions, the cells were analyzed by flow cytometry (FACS Aria III, USA). Data were processed by ModFit LT software.

Cell Dead/Live Assay. A375 cells were treated with $\mathrm{Cu}_{6} \mathrm{NC}(0,2,8$ and $16 \mu \mathrm{M})$ for $24 \mathrm{~h}$. Before being observed with a fluorescence microscope, the cells were washed twice with PBS and incubated with $2 \mu \mathrm{M}$ calcein $\mathrm{AM}$ and $4.5 \mu \mathrm{M} \mathrm{PI}$ for 20 minutes. For flow cytometry detection, after being digested and 
harvested, the cells are washed twice by PBS and then tested by a FACS Aria III flow cytometer. Data were processed and analyzed by FlowJo software.

Transwell migration assay. Migration assays of A375 in vitro were performed using a 24-well plate with a transwell polycarbonate permeable support (pore size, $8 \mu \mathrm{m}$; Corning Incorporated, Corning, USA). A375 cells were incubated and treated as described in the Apoptosis Assay. The harvested cells were resuspended in FBS-free medium and seeded in the upper chamber with $1 \times 10^{5}$ cells per well. The lower chamber was filled with $20 \%$ FBS medium ( $600 \mu \mathrm{L} /$ well). The cells were then cultured for 48 hours. Finally, the cells in the lower layer of the upper chambers were fixed with $4 \%$ paraformaldehyde and stained with $0.1 \%$ crystal violet. Numbers of migrated cells were photographed with a fluorescence microscopy and processed by Image J software.

Colony Formation Ability Identification. A375 cells were incubated and treated as described in the Apoptosis Assay. The cells were digested and seeded in 6-well plates (1000 cells per well). Then the cells are cultured in complete medium, and the medium was changed every 4 days. At 12 days, the cells were fixed with $4 \%$ paraformaldehyde and stained with $0.1 \%$ crystal violet. The cell colonies were observed and photographed with a microscope, and the colonies containing more than 50 cells were counted using Image J software.

Intracellular Reactive Oxygen Specie (ROS) Generation. A375 cells ( $5 \times 10^{4}$ cells/well) were incubated in a 24-well plate with different concentrations of $\mathrm{Cu}_{6} \mathrm{NC}(0,2,8$ and16 $\mu \mathrm{M})$ for $12 \mathrm{~h}$. Then, the level of cellular ROS was measured by 2',7-dichlorodihydrofluorescein diacetate (DCFH-DA) probe (Beyotime Biotechnology, Jiangsu, China). Firstly, the cells were washed twice with PBS, incubated with DCFH-DA $(10 \mu \mathrm{M})$ for 25 minutes, and then washed with PBS three times. Finally, the ROS signal of the cells was observed by a fluorescence microscopy.

Assessment of Glutathione (GSH). Levels of GSH in A375 cells after treatment with $\mathrm{Cu}_{6} \mathrm{NC}$ were evaluated with GSH and GSSG assay kits (Beyotime Biotechnology, Jiangsu, China). In short, A375 cells were seeded in 6-well dishes $\left(2 \times 10^{5}\right.$ cells per well) and treated with different concentrations of $\mathrm{Cu}_{6} \mathrm{NC}(0$, 2,8 and $16 \mu \mathrm{M}$ ) for $6 \mathrm{~h}$. Then, the cells were collected with centrifugation, and the supernatant was discarded. Samples were added protein remover $M(10 \mathrm{mg} / 30 \mu \mathrm{L})$, subjected to 3 cycles of freezing thawing, and then centrifugated at $1000 \mathrm{~g}$ for $10 \mathrm{~min}$ at $4^{\circ} \mathrm{C}$. The supernatant was reserved for $\mathrm{GSH}$ measurement with GSH and GSSG assay kits according to the manufacturer's protocol.

In vivo Chemodynamic Therapy. All animal procedures were conducted in accordance with the Guide for the Care and Use of Laboratory Animals and were approved by the Welfare and Ethics Review Committee of Zhengzhou University Laboratory Animal Center (Approval number: ZZU-LAC20200911[14]). In order to generate a xenograft mouse model, on day 0 , we planted A375 cells ( $5 \times 10^{6}$ tumor cells in $200 \mu \mathrm{L}$ of PBS) in 6-week-old female BALB/c nude mice (Beijing Vital River Laboratory Animal Technology Co. Ltd, China) subcutaneously in the right flank. When the tumor volume reached about $100 \mathrm{~mm}^{3}$ on the 4 th day, we randomly divided the mice into three groups: normal control group (NC), Cu6 NPs group (10 mg/kg), and 
$\mathrm{Cu}_{6} \mathrm{NC}$ group $(20 \mathrm{mg} / \mathrm{kg})$, at the same time by intraperitoneal injection corresponding dose of Cu6 NPs to treat mice. Mice were exposed to these treatments every other day for a total of nine administrations. The length $(\mathrm{L})$ and width $(\mathrm{W})$ of the tumor were measured with a vernier caliper every two days, and the tumor volume $(V)$ was calculated using the formula: $V=L \times W^{2} / 2$. On the 20th day, the tumor tissues, peripheral blood, and major organs (heart, liver, spleen, lungs and kidneys) of mice were harvested.

All harvested tissues were fixed with $4 \%$ formalin at least for 48 hours. The fixed tissue is used for experiments such as hematoxylin and eosin (H\&E) and immunohistochemistry staining. Apoptosis of tumor tissue sections was detected by staining with terminal deoxynucleotidyl transferase dUTP nick end labeling (TUNEL). The proliferation of tumor tissue was detected by immunohistochemical Ki67 staining. $\mathrm{H} \& \mathrm{E}$ were used to stain sections of major organs in each group. All these stained sections could be observed with a fluorescence microscopy. After the peripheral blood was collected, a serum sample was obtained by centrifugation. Then, an automatic biochemical analyzer (Chemray 240 or 840 , Rayto, China) was used to detect the indexes of liver function, kidney function and myocardial enzymes.

Statistical Analysis. All results are presented as the mean \pm standard deviation (SD). Two treatment groups were compared by Student's t test. Multiple group comparisons were performed by two-way analysis of variance with Tukey's post hoc test. All statistical analyses were carried out using GraphPad Prism 5. ${ }^{\star} p<0.05,{ }^{* \star} p<0.01,{ }^{* \star *} p<0.001$ and ${ }^{* \star * \star} p<0.0001$ were deemed as significant differences. "NS" indicates no significant differences.

\section{Declarations}

Acknowledgements

The authors greatly appreciate the financial support from the National Science Fund for Distinguished Young Scholars (No. 21825106) and the National Natural Science Foundation of China (No. 22005273 and 802073168).

\section{Authors' contributions}

P.P., B.L. and S.Z. conceived various aspects of the project. Z.Y. and A.Y. performed all experiments on synthesis and characterize of metal nanoclusters, in vitro and in vivo experiments, data collection and analysis. W.M, K.M and Y.L performed experiments on chemical and morphological characterizations of nanoclusters and worked on data analysis. P.P. and Z.Y. wrote the manuscript with input from other authors. \#Z.Y. and A.Y. contributed equally to this work.

Availability of data and materials

The datasets supporting the conclusions of this article are included within the article and its additional file.

Ethics approval and consent to participate 
All animal procedures were conducted in accordance with the Guide for the Care and Use of Laboratory Animals and were approved by the Welfare and Ethics Review Committee of Zhengzhou University Laboratory Animal Center (Approval number: ZZU-LAC20200911[14])

Consent for publication

All authors consent to publish.

Competing interests

The authors declare no confict of interest.

\section{References}

1. Sayin VI, Ibrahim MX, Larsson E, Nilsson JA, Lindahl P, Bergo MO. Antioxidants Accelerate Lung Cancer Progression in Mice. Sci Transl Med. 2014;6:8.

2. Cui Q, Wang JQ, Assaraf YG, Ren L, Gupta P, Wei LY, Ashby CR, Yang DH, Chen ZS. Modulating ROS to overcome multidrug resistance in cancer. Drug Resist Updates. 2018;41:1-25.

3. Yu XY, Lao YM, Teng XL, Li S, Zhou Y, Wang FX, Guo XW, Deng SY, Chang YZ, Wu XF, Liu ZD, Chen L, Lu LM, Cheng JK, Li B, Su B, Jiang J, Li HB, Huang CX, Yi J, Zou Q. SENP3 maintains the stability and function of regulatory T cells via BACH2 deSUMOylation. Nat Commun. 2018;9:11.

4. De Nicola GM, Karreth FA, Humpton TJ, Gopinathan A, Wei C, Frese K, Mangal D, Yu KH, Yeo CJ, Calhoun ES, Scrimieri F, Winter JM, Hruban RH, lacobuzio-Donahue C, Kern SE, Blair IA, Tuveson DA. Oncogene-induced Nrf2 transcription promotes ROS detoxification and tumorigenesis. Nature. 2011;475:106-28.

5. Lu Y, Chen B, Song JH, Zhen T, Wang BY, Li X, Liu P, Yang X, Zhang QL, Xi XD, Chen SD, Zuo JP, Chen $Z$, Chen SJ. Eriocalyxin B ameliorates experimental autoimmune encephalomyelitis by suppressing Th1 and Th17 cells. Proc Natl Acad Sci USA. 2013;110:2258-63.

6. Hultqvist M, Olofsson P, Gelderman KA, Holmberg J, Holmdahl R. A new arthritis therapy with oxidative burst inducers. Plos Medicine. 2006;3:1625-36.

7. Chen X, Stewart E, Shelat AA, Qu CX, Bahrami A, Hatley M, Wu G, Bradley C, McEvoy J, Pappo A, Spunt S, Valentine MB, Valentine V, Krafcik F, Lang WH, Wierdl M, Tsurkan L, Tolleman V, Federico SM, Morton C, Lu C, Ding L, Easton J, Rusch M, Nagahawatte P, Wang JM, Parker M, Wei L, Hedlund E, Finkelstein D, Edmonson M, Shurtleff S, Boggs K, Mulder H, Yergeau D, Skapek S, Hawkins DS, Ramirez N, Potter PM, Sandoval JA, Davidoff AM, Mardis ER, Wilson RK, Zhang JH, Downing JR, Dyer MA. St Jude Childrens Res H. Targeting Oxidative Stress in Embryonal Rhabdomyosarcoma. Cancer Cell. 2013;24:710-24.

8. Love NR, Chen YY, Ishibashi S, Kritsiligkou P, Lea R, Koh Y, Gallop JL, Dorey K, Amaya E. Amputationinduced reactive oxygen species are required for successful Xenopus tadpole tail regeneration. Nat Cell Biol. 2013;15:222-8. 
9. Gauron C, Rampon C, Bouzaffour M, Ipendey E, Teillon J, Volovitch M, Vriz S. Sustained production of ROS triggers compensatory proliferation and is required for regeneration to proceed. Sci Rep. 2013;3:9.

10. Kleinauskas A, Rocha S, Sahu S, Sun YP, Juzenas P. Carbon-core silver-shell nanodots as sensitizers for phototherapy and radiotherapy. Nanotechnology. 2013;24:10.

11. Goswami N, Luo ZT, Yuan X, Leong DT, Xie JP. Engineering gold-based radiosensitizers for cancer radiotherapy. Mater Horiz. 2017;4:817-31.

12. Su X-Y, Liu P-D, Wu H, Gu N. Enhancement of radiosensitization by metal-based nanoparticles in cancer radiation therapy. Cancer biology medicine. 2014;11:86-91.

13. Jin RC, Zeng CJ, Zhou M, Chen YX. Atomically Precise Colloidal Metal Nanoclusters and Nanoparticles: Fundamentals and Opportunities. Chemical Reviews. 2016;116:10346-413.

14. Chakraborty I, Pradeep T. Atomically Precise Clusters of Noble Metals: Emerging Link between Atoms and Nanoparticles. Chem Rev. 2017;117:8208-71.

15. Ghosh A, Mohammed OF, Bake OM. Atomic-Level Doping of Metal Clusters. Acc Chem Res. 2018;51:3094-103.

16. Sharma S, Chakrahari KK, Saillard JY, Liu CW. Structurally Precise Dichalcogenolate-Protected Copper and Silver Superatomic Nanoclusters and Their Alloys. Acc Chem Res. 2018;51:2475-83.

17. Lei Z, Wan XK, Yuan SF, Guan ZJ, Wang QM. Alkynyl Approach toward the Protection of Metal Nanoclusters. Acc Chem Res. 2018;51:2465-74.

18. Sakthivel NA, Dass A. Aromatic Thiolate-Protected Series of Gold Nanomolecules and a Contrary Structural Trend in Size Evolution. Acc Chem Res. 2018;51:1774-83.

19. Kwak K, Lee D. Electrochemistry of Atomically Precise Metal Nanoclusters. Acc Chem Res. 2019;52:12-22.

20. Tang Q, Hu GX, Fung V, Jiang DE. Insights into Interfaces, Stability, Electronic Properties, and Catalytic Activities of Atomically Precise Metal Nanoclusters from First Principles. Acc Chem Res. 2018;51:2793-802.

21. Jiang XY, Du BJ, Zheng J. Glutathione-mediated biotransformation in the liver modulates nanoparticle transport. Nat Nanotechnol. 2019;14:874-+.

22. Chakraborty P, Nag A, Chakraborty A, Pradeep T. Approaching Materials with Atomic Precision Using Supramolecular Cluster Assemblies. Acc Chem Res. 2019;52:2-11.

23. Nonappa IO. Hydrogen Bonding Directed Colloidal Self-Assembly of Nanoparticles into 2D Crystals, Capsids, and Supracolloidal Assemblies. Adv Func Mater. 2018;28:14.

24. Zhang XD, Luo ZT, Chen J, Shen X, Song SS, Sun YM, Fan SJ, Fan FY, Leong DT, Xie JP. Ultrasmall Au10-12(SG)(10-12) Nanomolecules for High Tumor Specificity and Cancer Radiotherapy. Adv Mater. 2014;26:4565-+.

25. Liang GH, Jin XD, Zhang SX, Xing D. RGD peptide-modified fluorescent gold nanoclusters as highly efficient tumor-targeted radiotherapy sensitizers. Biomaterials. 2017;144:95-104. 
26. Chen Q, Chen JW, Yang ZJ, Xu J, Xu LG, Liang C, Han X, Liu Z. Nanoparticle-Enhanced Radiotherapy to Trigger Robust Cancer Immunotherapy. Adv Mater. 2019;31:12.

27. Yi X, Chen L, Chen J, Maiti D, Chai ZF, Liu Z, Yang K. Biomimetic Copper Sulfide for ChemoRadiotherapy: Enhanced Uptake and Reduced Efflux of Nanoparticles for Tumor Cells under lonizing Radiation. Adv Func Mater. 2018;28:11.

28. Juzenas P, Chen W, Sun YP, Coelho MAN, Generalov R, Generalova N, Christensen IL. Quantum dots and nanoparticles for photodynamic and radiation therapies of cancer. Adv Drug Deliv Rev. 2008;60:1600-14.

29. Ghahremani F, Kefayat A, Shahbazi-Gahrouei D, Motaghi H, Mehrgardi MA, Haghjooy-Javanmard S. AS1411 aptamer-targeted gold nanoclusters effect on the enhancement of radiation therapy efficacy in breast tumor-bearing mice. Nanomedicine. 2018;13:2563-78.

30. Li B, Lv Y-K, Wang Z-D, Peng P, Zang S-Q. Edge confined covalent organic framework with efficient biocompatibility and photothermic conversion. Nano Today. 2021;37:101101.

31. Zhang MM, Dong XY, Wang ZY, Li HY, Li SJ, Zhao XL, Zang SQ. AIE Triggers the Circularly Polarized Luminescence of Atomically Precise Enantiomeric Copper(I) Alkynyl Clusters. Angewandte ChemieInternational Edition. 2020;59:10052-8.

32. Huang JH, Wang ZY, Zang SQ, Mak TCW. Spontaneous Resolution of Chiral Multi-Thiolate-Protected Ag-30 Nanoclusters. Acs Central Science. 2020;6:1971-6.

33. Li HY, Zhao SN, Zang SQ, Li J. Functional metal-organic frameworks as effective sensors of gases and volatile compounds. Chem Soc Rev. 2020;49:6364-401.

34. Han Z, Zhao XL, Peng P, Li S, Zhang C, Cao M, Li K, Wang ZY, Zang SQ. Intercluster aurophilicitydriven aggregation lighting circularly polarized luminescence of chiral gold clusters. Nano Research. 2020;13:3248-52.

35. Dong XY, Si YB, Yang JS, Zhang C, Han Z, Luo P, Wang ZY, Zang SQ, Mak TCW. Ligand engineering to achieve enhanced ratiometric oxygen sensing in a silver cluster-based metal-organic framework. Nat Commun. 2020;11:9.

36. Kong YJ, Yan ZP, Li S, Su HF, Li K, Zheng YX, Zang SQ. Photoresponsive Propeller-like Chiral AIE Copper(I) Clusters. Angewandte Chemie-International Edition. 2020;59:5336-40.

37. Jin Y, Li S, Han Z, Yan BJ, Li HY, Dong XY, Zang SQ. Cations Controlling the Chiral Assembly of Luminescent Atomically Precise Copper(I) Clusters. Angewandte Chemie-International Edition. 2019;58:12143-8.

38. Huang Q, Zhang SH, Zhang H, Han YB, Liu HH, Ren F, Sun Q, Li Z, Gao MY. Boosting the Radiosensitizing and Photothermal Performance of Cu2-xSe Nanocrystals for Synergetic Radiophotothermal Therapy of Orthotopic Breast Cancer. Acs Nano. 2019;13:1342-53.

39. Jin Y, Zhang C, Dong XY, Zang SQ, Mak TCW. Shell engineering to achieve modification and assembly of atomically-precise silver clusters. Chem Soc Rev. 2021;50:2297-319.

40. Hu K, Xie L, Zhang YD, Hanyu M, Yang ZM, Nagatsu K, Suzuki H, Ouyang J, Ji XY, Wei JJ, Xu H, Farokhzad OC, Liang SH, Wang L, Tao W, Zhang MR. Marriage of black phosphorus and Cu2 + as 
effective photothermal agents for PET-guided combination cancer therapy. Nat Commun. 2020;11:15.

41. Liu Y, Wu JD, Jin YH, Zhen WY, Wang YH, Liu JH, Jin LH, Zhang ST, Zhao Y, Song SY, Yang Y, Zhang HJ. Copper(I) Phosphide Nanocrystals for In Situ Self-Generation Magnetic Resonance ImagingGuided Photothermal-Enhanced Chemodynamic Synergetic Therapy Resisting Deep-Seated Tumor. Adv Func Mater. 2019;29:8.

42. Zhou RS, Zhang XY, Fu J, Xin LD, Jiao WZ, Song JF. Four new Cu6S6 cluster-based coordination compounds: synthesis, crystal structures and fluorescence properties. Dalton Trans. 2021;50:456776.

\section{Figures}


a
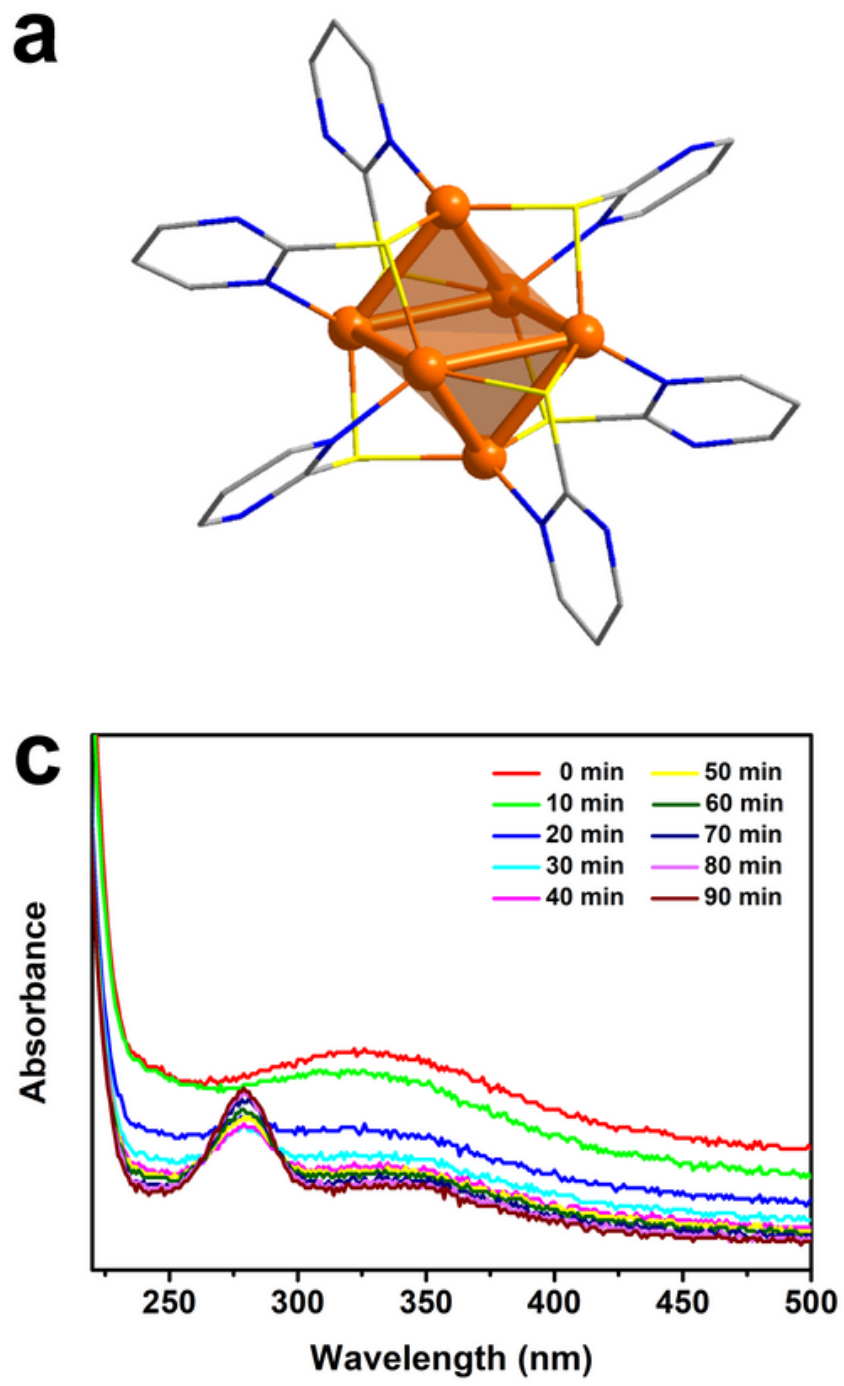

e

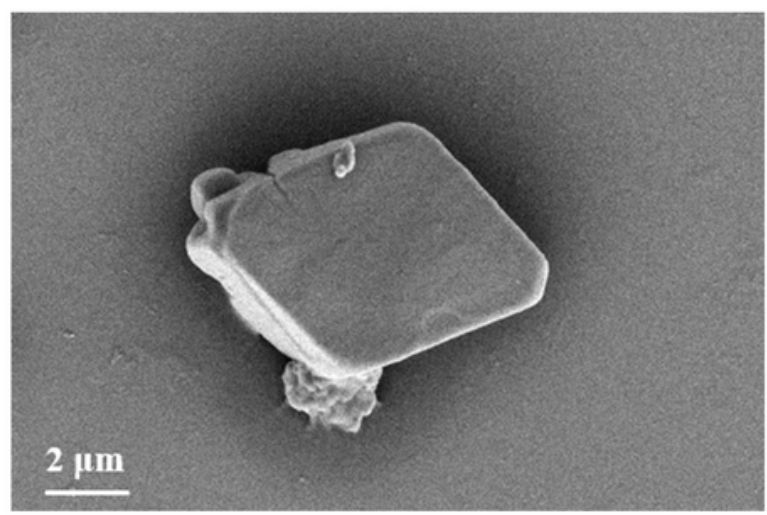

b

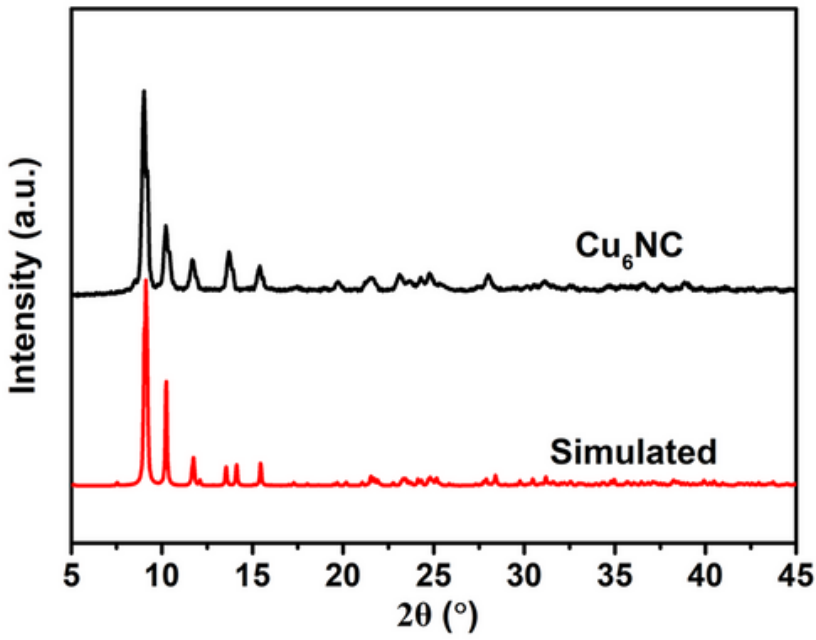

d

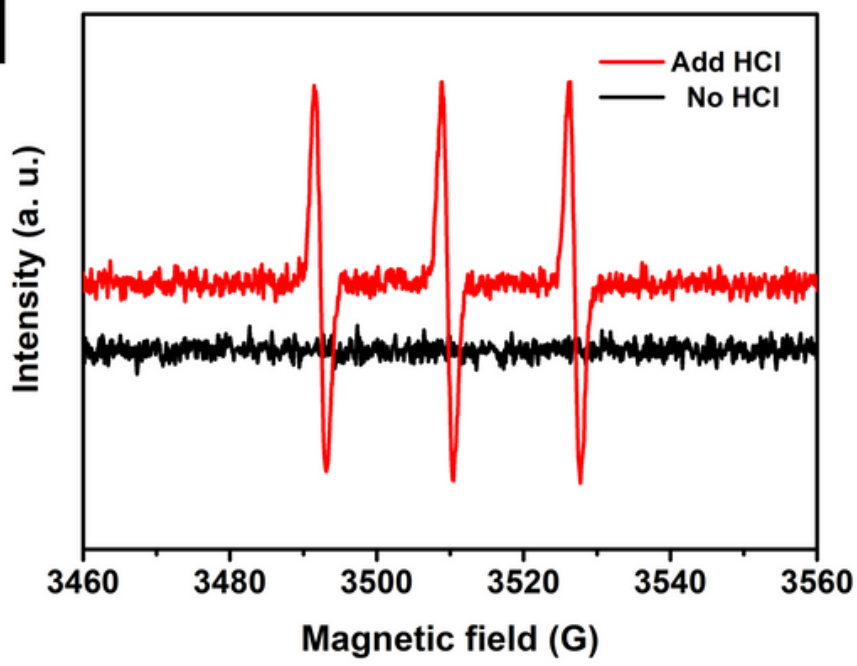

f

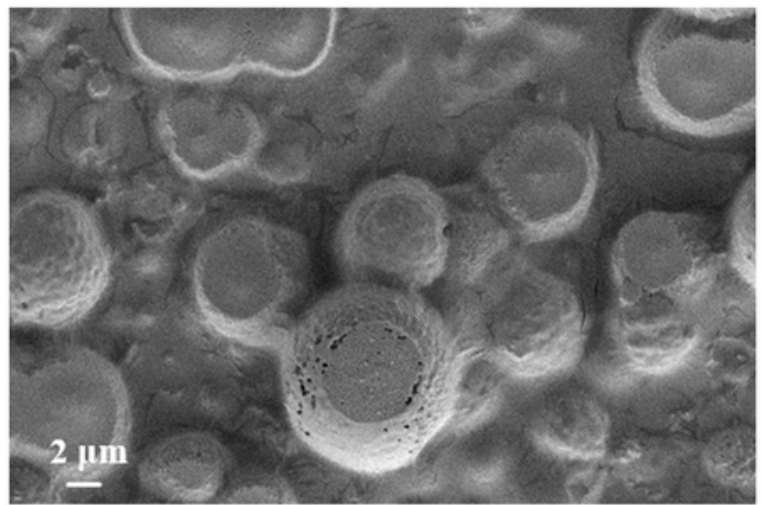

Figure 1

In vitro characterization of Cu6NC. a) The molecular structure of Cu6NC. b) The experimental PXRD patterns and the simulated ones from the SC-XRD of Cu6NC, which were in good agreement. c) The

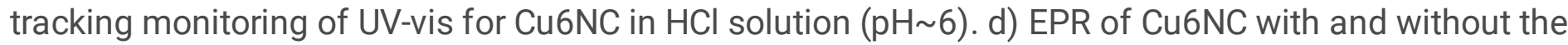
addition of $\mathrm{HCl}$ solution ( $\mathrm{pH} 6$ ). The emerging peaks indicated the generation of ROS once $\mathrm{HCl}$ was 
added. e) SEM images of the crystalline Cu6NC. Clearly shape could be observed. f) SEM images of Cu6NC after the treatment of $\mathrm{HCl}$ solution ( $\mathrm{pH} 6)$. The crystals were totally pulverized.

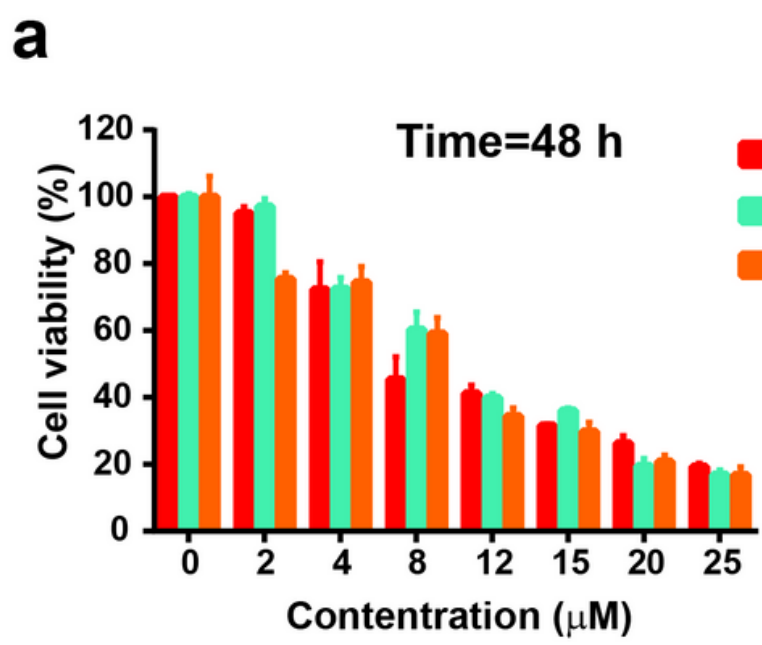

C

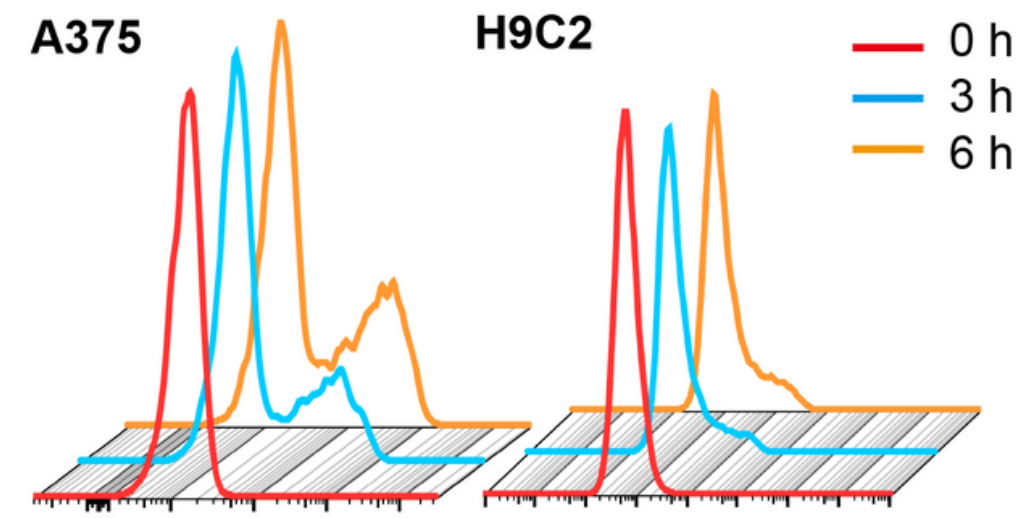

e

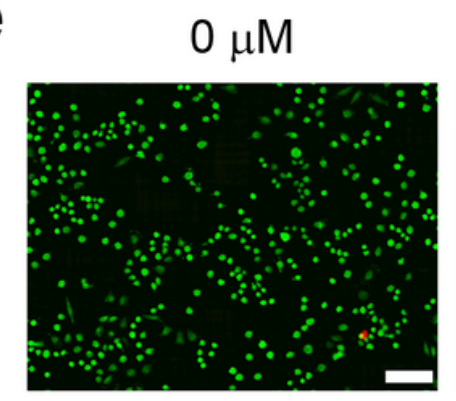

b

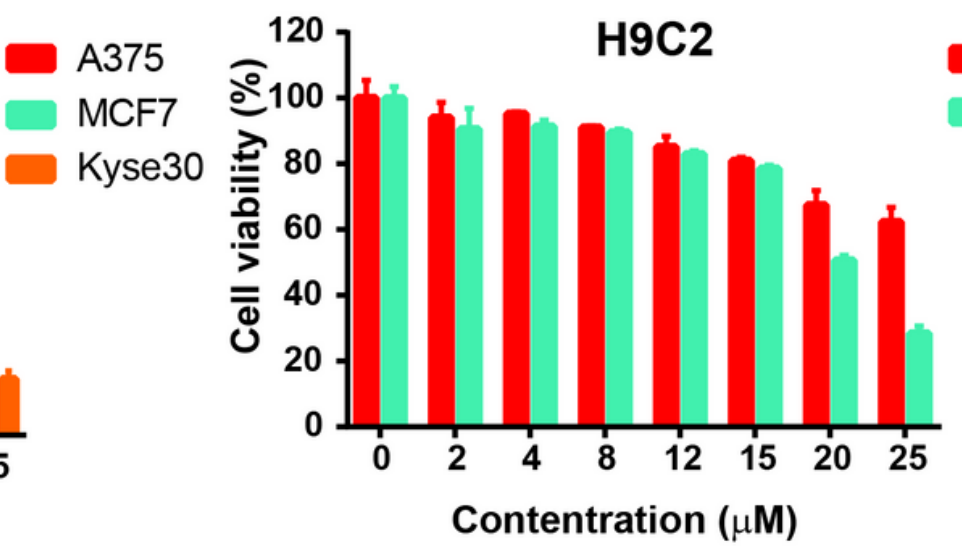

d

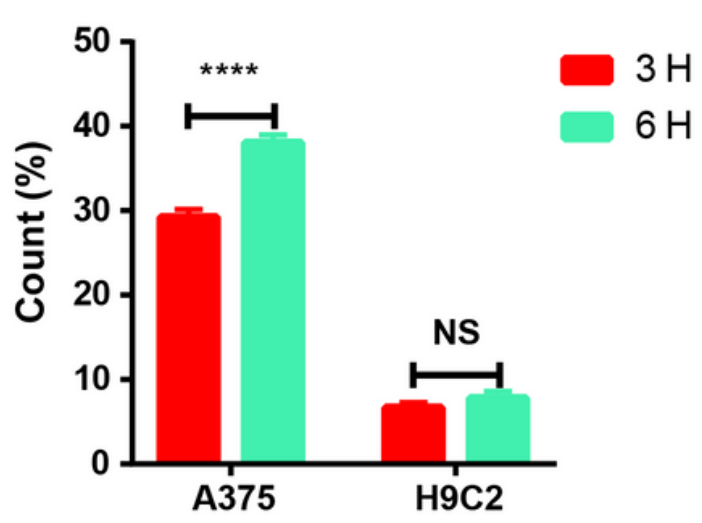

$8 \mu \mathrm{M}$

$16 \mu \mathrm{M}$
$24 \mathrm{~h}$ $48 \mathrm{~h}$ 
cellular uptake capacity of Cu6NC after the incubation of different durations for A375 cells and $\mathrm{H} 9 \mathrm{C} 2$ cells. e) Live/dead imaging of A735 cells after receiving different treatments. Scale bar: $50 \mu \mathrm{m}$.

a
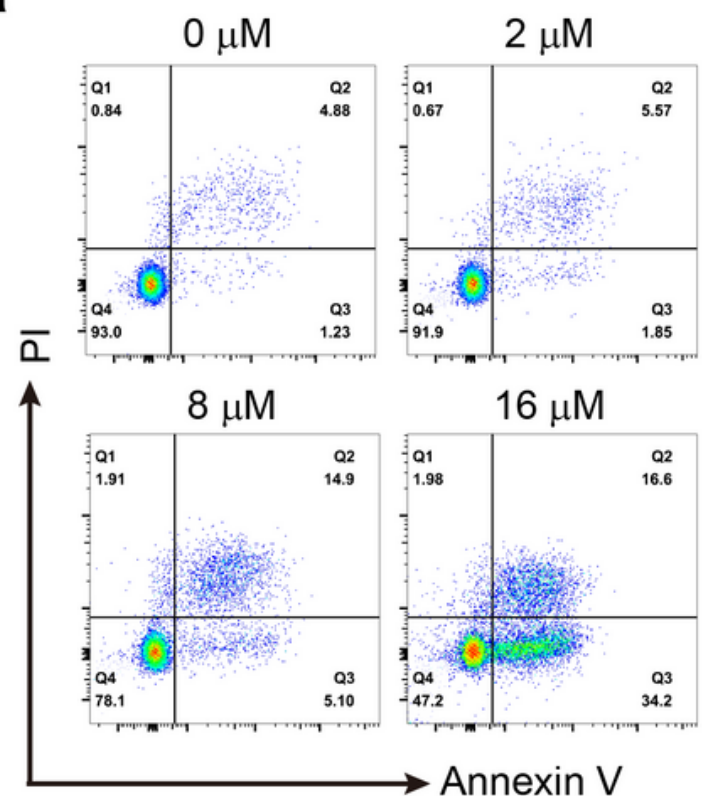

C

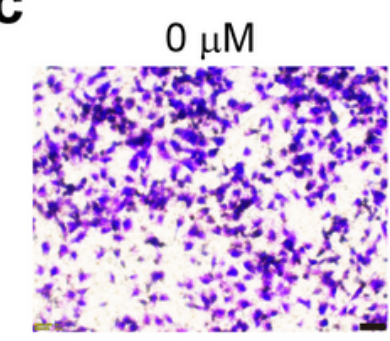

d
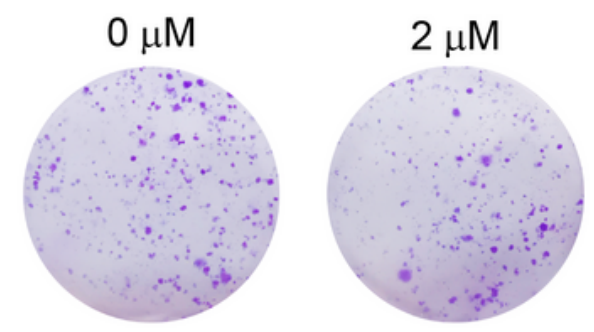

$8 \mu \mathrm{M}$

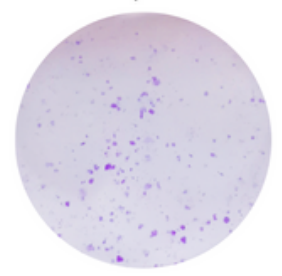

b

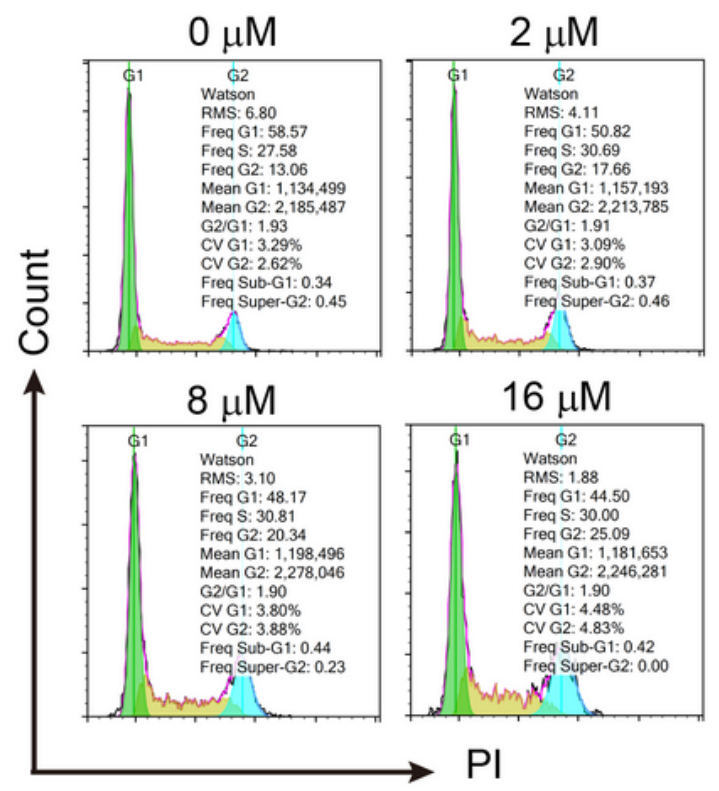

$8 \mu \mathrm{M}$

$16 \mu \mathrm{M}$
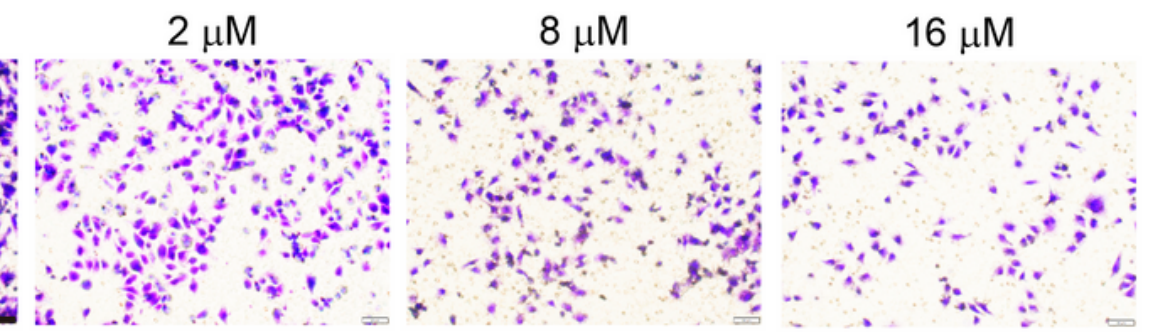

e
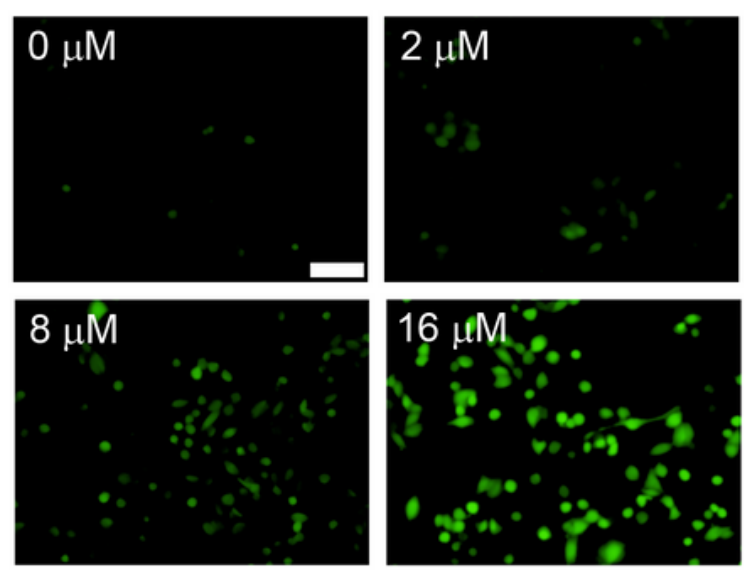

Figure 3

Chemokinetic anti-tumor properties of Cu6NC. Cell flow cytometry analysis for apoptosis a) and cell cycle b) distribution in A735 cells after different concentrations $(0,2,8$ and16 $\mu \mathrm{M})$ of Cu6NC treatment. $\mathrm{c})$ Representative images of transwell migration assay. Scale bar: $50 \mu \mathrm{m}$. d) Typical images representing the 
colony formation ability of A735 cells with different treatments. e) ROS production in A375 cells after Cu6NC treatment. Scale bar: $100 \mu \mathrm{m}$.

a

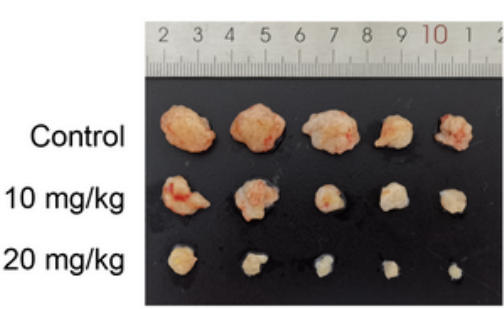

b

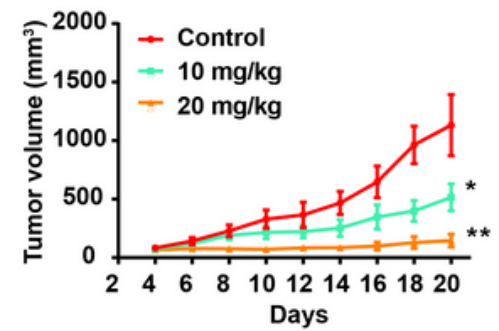

C

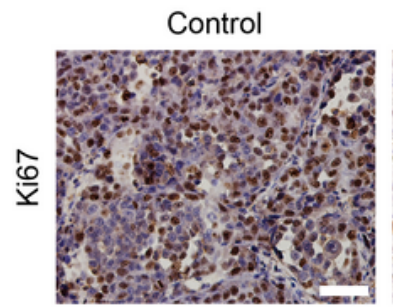

$10 \mathrm{mg} / \mathrm{kg}$

$20 \mathrm{mg} / \mathrm{kg}$
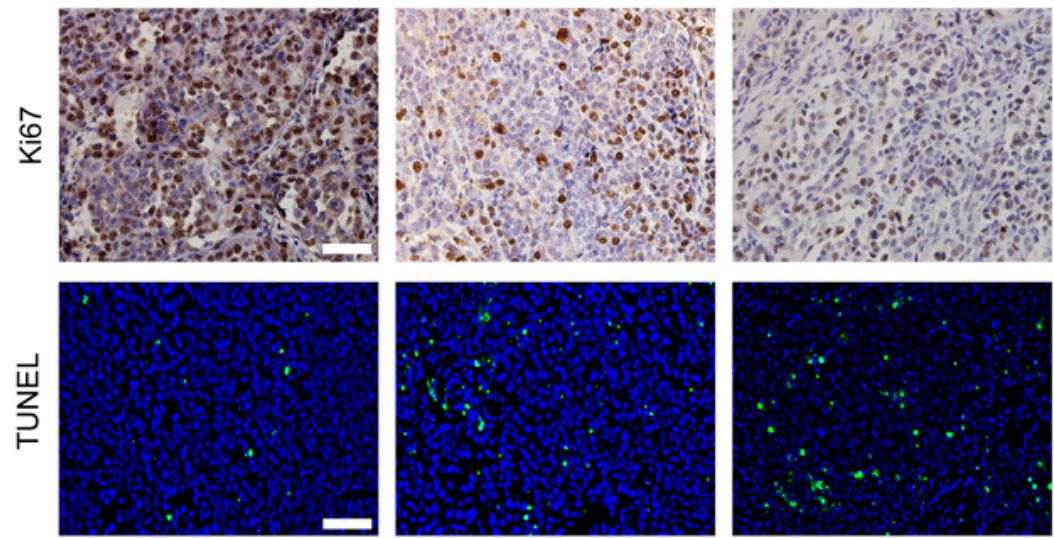

d
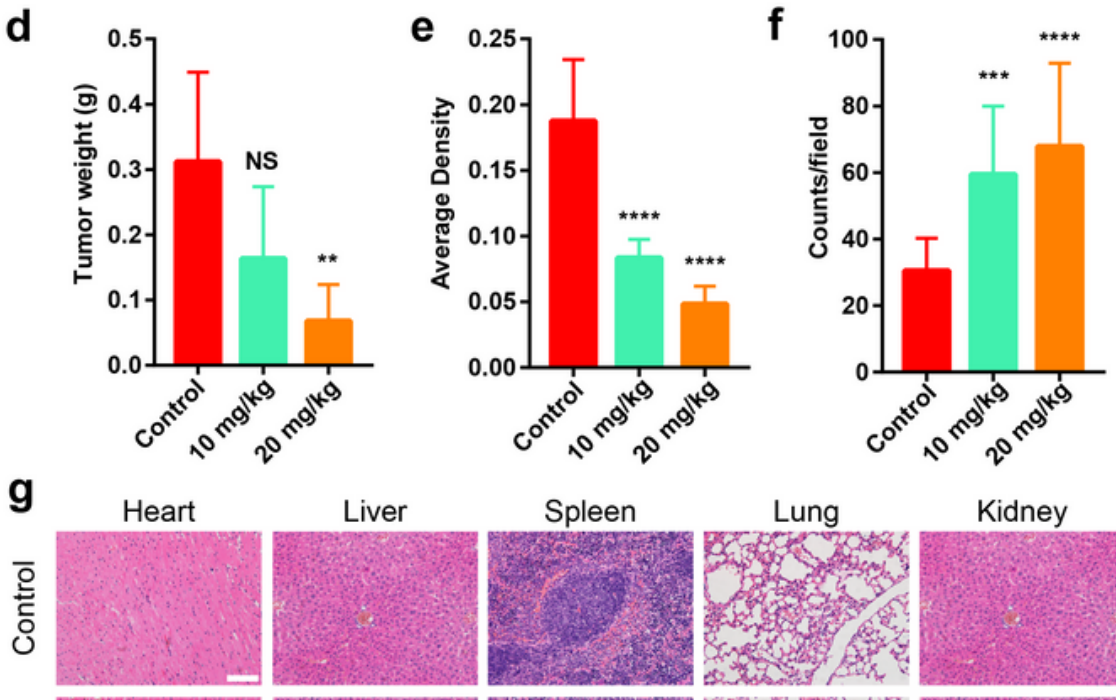

Kidney
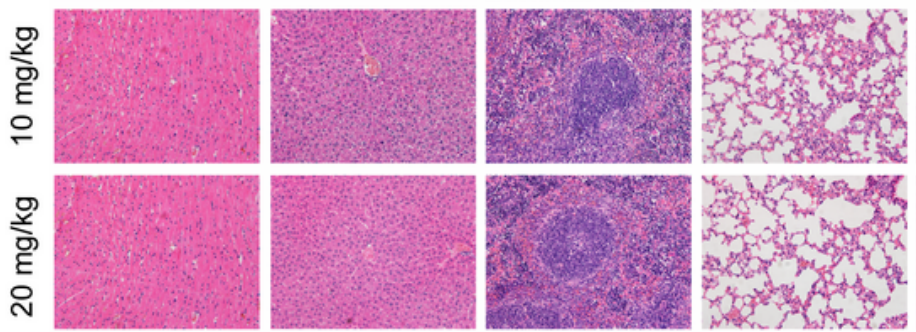

\section{Figure 4}

In vivo cancer chemotherapy results of Cu6NC. a) Photographs of mice after 16 days of different formulations. b) Tumor growth curves of mice in different treatment groups. c) Ki67 staining and TUNEL staining of tumor sections from different treatment groups. Scale bar: $100 \mu \mathrm{m}$. d) Comparison of tumor 
weight in mice after therapy. The quantitative analysis of Ki67 e) and TUNEL f) performed by Image $J$ software. g) Pathological analysis of various organs in mice injected with different formulations. Scale bar: $50 \mu \mathrm{m}$.

\section{Supplementary Files}

This is a list of supplementary files associated with this preprint. Click to download.

- Additionalfile1.docx

- Scheme1.png 